\title{
EFEKTIVITAS BEBERAPA JENIS BIOINSEKTISIDA TERHADAP KEANEKARAGAMAN DAN POPULASI ARTHROPODA PADA EKOSISTEM PADI SAWAH
}

\section{(Effectiveness of Several Types of Bioinsecticides on Arthropod Diversity and Population in Rice Field Ecosystems)}

\author{
${ }^{1)}$ Andi Dian Tristiana Kusuma, ${ }^{2)}$ Ayu K. Parawansa, ${ }^{2)}$ St Subaedah \\ ${ }^{1)}$ Mahasiswa Program Studi Agroekoteknologi Program Pascasarjana UMI \\ ${ }^{2)}$ Dosen Program Studi Agroteknologi Fakultas Pertanian UMI \\ ${ }^{1)}$ Email: andiantrikusuma@gmail.com \\ ${ }^{2)}$ Email : st.subaeda@umi.ac.id
}

\begin{abstract}
Bioinsecticides have the potential to affect arthropod populations in lowland rice ecosystems. The purpose of this study are 1) Knowing the effect of Beauveria bassiana, Metarhizium anisopliae and Verticillium lecanii on population and diversity of arthropods and 2) Knowing the effectiveness of giving 0.5 gram / 1.4 liter of water and 1 gram / 1.4 liter of water to each bioinsecticide on Arthropod population and diversity was carried out in Turikale District, February 2019 until April 2019. This study used a 2 factorial randomized block design. The first factor is the type of bioinsecticide and the second factor is the bioinsecticide dose of data analysis using Anova in the STAR 2.0.1 2013 program to see the average number of arthropod populations in each treatment. The results of the study showed that 1) The administration of Beauveria bassiana, Metarhizium anisopliae and Verticillium lecanii affected the population but did not affect the diversity of arthropods. 2) Each dose of 0.5 gram / 1.4 liter of water and 1 gram / 1.4 liter of water in each bioinsecticide effectively suppresses the arthropod population of the herbivorous group. Which means the use of bioinsecticides on diversity and arthropod populations in rice plants is feasible to be developed.
\end{abstract}

Keywords : Bioinsecticide; Beauveria bassiana; Metarhizium anisopliae; Verticillium lecanii; arthropod diversit; arthropod population

\section{PENDAHULUAN}

Padi salah satu komoditas strategis dan menjadi prioritas utama bangsa Indonesia dalam menunjang ketahanan pangan nasional, karena sebagian besar penduduk Indonesia bergantung hidup pada komoditi ini. Meskipun padi dapat digantikan oleh makanan lainnya, namun padi memiliki nilai tersendiri bagi orangorang yang biasa makan nasi dan tidak dapat dengan mudah digantikan oleh bahan makanan yang lain.
Tanaman padi merupakan tanaman semusim termasuk golongan rumputrumputan (Ginting, 2012). Tanaman padi (Oryza sativa L.) merupakan salah satu tanaman pangan yang banyak di budidayakan oleh petani yang dijadikan sebagai makanan pokok oleh lebih dari setengah penduduk indonesia (Aribawa, 2012).

Beras merupakan bahan pangan pokok bagi $95 \%$ dari penduduk Indonesia. Sejak awal kemerdekaan Indonesia telah 
berusaha keras untuk meningkatkan produksi padi. Namun demikian, selama lebih dari tiga dekade Indonesia belum mampu memenuhi kebutuhan beras dalam negeri, sehingga masih tergantung pada impor (Swastika, 2016).

Penurunan produksi padi diakibatkan rusaknya ekosistem akibat penggunaan pupuk kimia yang berlebihan yang merusak struktur tanah sehingga organisme tanah yang diduga sebagai agen pengendali hayati tidak dapat hidup secara sempurna serta penggunaan insektisida yang melebihi dosis yang dianjurkan sehingga mengurangi jumlah keragaman arthropoda yang kemungkinan dapat hidup sebagai agen hayati di lapangan.

Keanekaragaman spesies merupakan salah satu tema utama dalam penelitian ekologi. Banyak penelitian telah dilakukan untuk mempelajari bagaimana pengaruh perubahan kondisi lingkungan terhadap keanekaragaman spesies dan bagaimana keanekaragaman spesies mempengaruhi stabilitas komunitas alami.

Serangan hama dan penyakit di lapangan juga merupakan salah satu faktor yang menurunkan produksi tanaman padi. Peledakan hama dapat terjadi akibat penggunaan dosis instektisida yang berlebihan, tidak sesuai anjuran sehingga merusak ekosistem alami tanaman padi.

Upaya peningkatan produksi padi dihadapkan pada masalah serangan hama. Untuk mengendalikan hama tersebut, petani umumnya menggunakan insektisida secara berlebihan sehingga berdampak negatif terhadap bioekologi lahan sawah. oleh karena itu, dianjurkan teknik pengendalian secara terintegrasi dengan mengutamakan lingkungan sehat dan meningkatkan peran serangga berguna seperti musuh alami. Pengendalian menggunakan musuh alami atau secara hayati telah diketahui sejak sebelum tahun 1945. Dasar pengendalian hayati secara ekologi yaitu membuat populasi hama serendah mungkin dan mengoptimalkan peran musuh alami (Kartohardjono, 2011).

Pengendalian hayati merupakan komponen dari pengendalian hama terpadu (PHT). Pada tahun 2008, PHT menjadi salah satu komponen pengelolaan tanaman terpadu (PTT) yang kemudian diperluas menjadi sekolah lapang pengelolaan tanaman terpadu (SLPTT). Strategi pengendalian dilakukan dengan aplikasi insektisida berdasarkan ambang ekonomi dan penggunaan musuh alami seperti parasitoid dan patogen serangga. Untuk lebih memasyarakatkan 
penggunaan musuh alami dapat menginfeksi serangga hama, namun juga dilaksanakan dengan meningkatkan dapat menginfeksi serangga bermanfaat partisipasi petani / kelompok tani maupun seperti predator (Permadi, 2010).

melalui media publikasi. Pengendalian

Verticillium lecanii merupakan salah hayati perlu dilakukan secara satu jenis jamur yang juga dimanfaatkan berkelanjutan dan ditunjang dengan dan diproduksi meskipun dalam skala penyediaan agens hayati yang siap dipakai kecil untuk mengendalikan hama dan di lapangan (Kartohardjono, 2011).

penyakit pada tanaman. Jamur ini bersifat

Produk agens hayati yang dapat parasit namun akan berubah menjadi diproduksi sendiri dalam skala yang kecil, diantaranya adalah Beauveria bassiana, Metarhizium anisopliae dan Verticillium lecanii yang dapat disebut sebagai bioinsektisida.

saprofit bila kondisi tidak menguntungkan.

Berdasarkan uraian tersebut diatas menenai biinsektisida, maka perlu dilakukan penelitian tentang "Efektivitas

Beauveria bassiana merupakan cendawan entomopatogen yang dapat beberapa jenis bioinsektisida terhadap keanekaragaman dan populasi Arthropoda menimbulkan penyakit pada serangga pada ekosistem padi sawah".

yang bersifat saprofit dantidak bisa

Penelitian ini bertujuan 1) Mengetahui memproduksi makanannya sendiri, maka dari itu jamur ini bersifat parasit dan hidup dari mengambil nutrisi inangnya. Cendawan ini ditemukan dipertanaman padi yang dapat menyerang hama-hama antara lain wereng batang, wereng daun, penggerek batang padi, penggulung daun, kepinding padi, kepinding hitam dan kutu banci (Suwahyono, 2009).

pengaruh pemberian Beauveria bassiana, Metarhizium anisopliae dan Verticillium lecanii terhadap populasi dan keanekaragaman arthropoda. 2) Mengetahui efektifitas pemberian dosis 0,5 gram/1,4 liter air dan 1 gram/1,4 liter air pada masing-masing bioinsektisida terhadap populasi dan keanekaragaman Arthropoda.

Metarhizium spp merupakan cendawan entomopatogen yang mempunyai kisaran inang luas. Cendawan Metarhizium spp tidak hanya dapat 
Andi Dian Tristiana Kusuma : Efektivitas beberapa Jenis Bioinsektisida terhadap Keanekaragaman dan Populasi Arthropoda pada Ekosistem Padi Sawah

\section{METODE PENELITIAN}

\section{Lokasi Penelitian}

Penelitian ini dilaksanakan di Kantor

Balai Proteksi Tanaman Pangan dan Hortikultura Sulawesi Selatan, Kecamatan Turikale, Kabupaten Maros. Penelitian dilakukan pada bulan Februari 2019 sampai dengan April 2019.

\section{Bahan dan Alat}

Bahan yang digunakan dalam penelitian ini meliputi: 3 jenis bioinsektisida yaitu Beuveria bassiana, Metarhizium anisopliae dan Verticilium lecanii, serta Air. Sedangkan Alat yang digunakan meliputi: papan penelitian (patok), spidol, kayu, pisau, tali, timbangan analitik, wadah (botol dan ember), gelas ukur, alat semprot (sprayer), alat tulis (pulpen, blanko pengamatan).

\section{Metode Pelaksanaan}

Penelitian ini disusun dalm bentuk Rancangan Acak Kelompok pola faktorial 2 faktor. Faktor pertama adalah jenis bioinsektisida yang terdiri dari: $\mathrm{P} 1=$ Perlakuan Beauveria bassiana, $\mathrm{P} 2=$ Perlakuan Metarhizium anisopliae, P3= Perlakuan Verticillium lecanii. Sebagai faktor kedua adalah dosis bioinsektisida yang terdiri dari 2 taraf yaitu: D1= Dosis
0,5 gram $/ 1,4$ liter air, D2 = Dosis 1 gram/1,4 liter air

Dari kedua faktor diperoleh 6 kombinasi perlakuan. Setiap perlakuan diulang 3 kali sehingga diperoleh 18 petak percobaan.

Persiapan lahan yang dilakukan yaitu Luas lahan yang digunakan yaitu 9,5 m x $20 \mathrm{~m}$, lahan dibagi menjadi 18 petak dimana tiap petakan mendapatkan perlakuan aplikasi bioinsektisida yang berbeda. Luas petakan masing-masing yaitu 2,5 $\mathrm{m}$ x 2,5 $\mathrm{m}$ dengan jarak antara petakan $1,5 \mathrm{~m}$. Pada saat penanaman, kondisi lahan dalam keadaan tidak tergenang. Benih padi varietas Ciliwung disemaikan di tepi sawah, setelah berumur 20 hari dilakukan penanaman pada lahan percobaan dengan jarak tanam $30 \mathrm{~cm}$ x 30 $\mathrm{cm}$.

Aplikasi bioinsektisida dilakukan secara bersamaan di petak yang berbeda sebanyak 4 kali dengan interval waktu 14 hari yaitu pada saat padi berusia 25 HST, 39 HST, 53 HST dan 67 HST. Bioinsektisida yang digunakan yaitu Beauveria bassiana, Metarhizium anisopliae dan Verticillium lecanii dengan dosis 50 gram/14 liter air dikonversi menjadi 0,5 gram/1,4 liter air dan 100 gram/14 liter air dikonversi menjadi 1 
gram/1,4 liter air pada masing-masing pengamatan dapat dilihat pada Gambar 1. jenisnya. Untuk pembagian petak

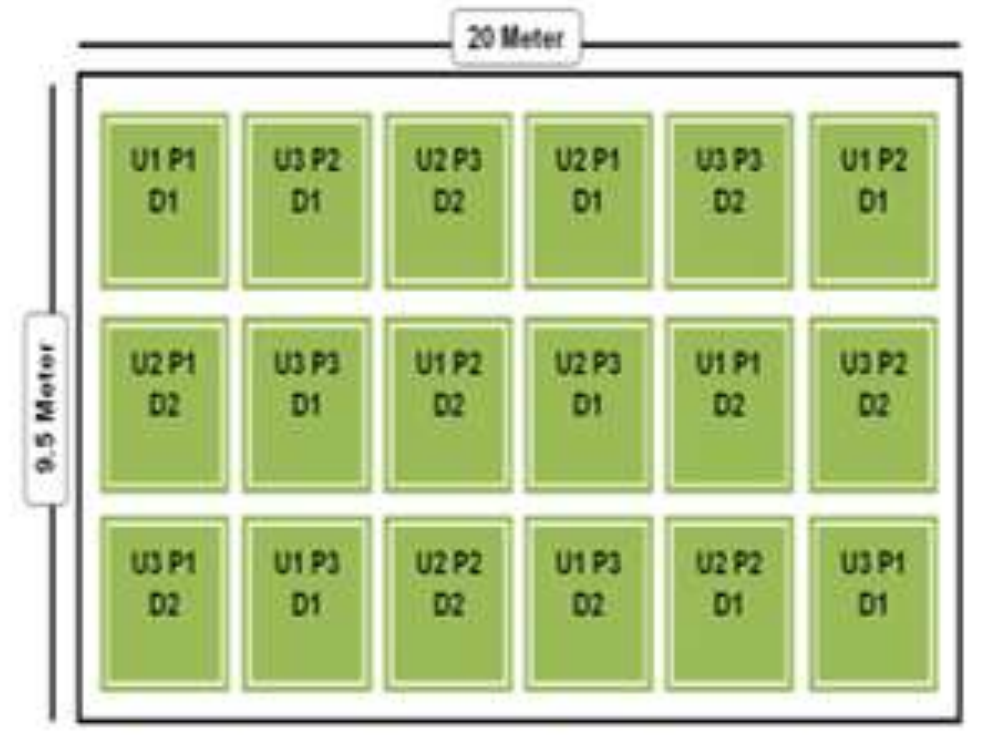

Gambar 1 Denah Petak Perlakuan

\section{HASIL DAN PEMBAHASAN}

\section{Kondisi Umum Lokasi Pelaksanaan}

Kabupaten Maros merupakan salah satu kabupaten di Provinsi Sulawesi Selatan, terletak dibagian barat Sulawesi Selatan antara 40'45'50'07' lintang selatan dan 109'205'-129'12' bujur timur yang berbatasan dengan kabupaten Pangkep sebelah utara, Kota Makassar dan Kabupaten Gowa sebelah Selatan, Kabupaten Bone disebelah Timur dan Selat Makassar disebelah Barat. Secara administratif, Kabupaten Maros terdiri atas 14 Kecamatan, 80 Desa dan 23 Kelurahan.

\section{Karakteristik Iklim Daerah Penelitian}

Kabupaten Maros termasuk daerah yang beriklim tropis, karena letaknya yang dekat dengan khatulistiwa dengan kelembaban berkisar antara $60-82 \%$. Daerah Kabupaten Maros pada dasarnya beriklim tropis dengan dua musim, berdasarkan curah hujan yakni Musim hujan pada periode bulan Oktober sampai Maret dan musim kemarau pada periode bulan April sampai September. Curah hujan tahunan rata-rata $347 \mathrm{~mm} / \mathrm{thn}$ dengan rata-rata hari hujan sekitar 16 hari. Temperatur udara rata-rata $29^{\circ} \mathrm{C}$. Kecepatan angin rata-rata $2-3 \mathrm{knot} / \mathrm{jam}$.

Pada bulan November sampai Maret angin 
bertiup dari arah barat, barat laut dan timur barat. Pada bulan Juni sampai Agustus angin bertiup dari arah barat dengan kecepatan rata-rata $7 \mathrm{~km} / \mathrm{jam}$. Pada Daerah Kabupaten Maros temperatur udara rata-rata berkisar antara $26^{\circ} \mathrm{C}$ dan $27,6^{\circ} \mathrm{C}$. Temperatur maksimum yang sangat jarang dialami adalah $34,6^{\circ} \mathrm{C}$ dan temperatur minimum $19,9^{\circ} \mathrm{C}$.

\section{Hasil Keanekaragaman Populasi Arthropoda}

Hasil analisis ragam menunjukkan jenis bioinsektisida dan dosis bioinsektisida tidak berpengaruh nyata terhadap keanekaragaman dan populasi arthropoda. Hal ini dapat dilihat pada Tabel lampiran 1 dan lampiran 2. Untuk hasil yang diperoleh dari keanekaragaman dan populasi arthropoda tiap perlakuan dapat dilihat pada Lampiran 3.

\section{Pembahasan}

Berdasarkan penelitian yang telah dilakukan maka diperoleh hasil bahwa pada perlakuan tersebut telah dilakukan uji F (anova) dan hasilnya dari keenam perlakuan tidak menunjukkan perbedaan yang signifikan pada keanekaragaman dan populasi arthropoda hal ini dapat dilihat pada tabel 5. dan tabel 6. dengan kata lain ketiga perlakuan ini memiliki efektifitas yang sama. Pada dasarnya, prinsip kerja cendawan entomopatogen tidak secepat insektisida sintetik yang dapat secara langsung mematikan serangga targetnya. Cendawan entomopatogen membutuhkan waktu yang lebih lama untuk mematikan serangga targetnya. Selama proses infeksi Beauveria bassiana menghasilkan sejumlah enzimselama perkecambahan dalam tubuh serangga seperti protese, kitinase dan lipase yang berfungsi untuk mendegradasi kutikula inang dan memfasilitasi perlekatan konidia Beauveria bassiana pada kutikula serangga inang (Boucias, 1998). Selain itu, Roberts (1977) melaporkan bahwa cendawan entomopatogen menghasilkan beberapa jenis toksin yang dalam mekanisme kerjanya akan menyebabkan terjadinya kenaikan $\mathrm{pH}$ hemolimfa, penggumpalan hemolimfa, dan terhentinya peredaran hemolimfa.

Beberapa toksin yang dihasilkan oleh Beauveria bassiana adalah beauverisin, beauverolit, bassianolit, isorolit dan asam oksalit. Sedang jenis toksin yang dihasilkan oleh Verticillium lecanii adalah Cyclosporin A. Antibiotik ini dapat menyebabkan gangguan pada fungsi hemolimfa dan nukleus serangga, sehingga mengakibatkan pembengkakan yang disertai pengerasan pada serangga 
yang terinfeksi (Vey, 2001). Tingkat patogenisitas antar cendawan entomopatogen kemungkinan disebabkan oleh perbedaan sifat dasar internal (genetik) dan perbedaan sumber inang asal isolat. Selain hal itu, juga disebabkan oleh pengaruh lingkungan sebagai faktor eksternal yang dapat berpengaruh terhadap kemampuan cendawan tumbuh dan berkembang serta melumpuhkan mekanisme pertahanan serangga inang. Menurut Tanada (1993), biasanya cendawan menyebabkan mortalitas dengan satu atau lebih cara seperti: defisiensi nutrisi, menyerang dan merusak jaringan, dan melepaskan toksin. Beberapa diantaranya bersifat virulen dan membunuh serangga dalam waktu yang singkat dan yang lainnya menghasilkan infeksi kronik yang lama.

Untuk perlakuan Beauveria bassiana dosis 0,5 gram $/ 1,4$ liter air adalah keanekaragaman arthropoda yang ada adalah untuk golongan karnivora yaitu laba-laba, capung, kepik predator dan coccinellid. Hal ini dapat dilihat pada Gambar 1 dimana populasi arthropoda karnivora yang bersifat musuh alami cenderung meningkat atau tidak mengalami penurunan, jumlah populasi laba-laba terlihat sangat tinggi ditiap minggunya jika dibandingkan dengan jumlah musuh alami lainnya. Hal ini sesuai dengan pendapat Herlinda (2016) bahwa Beauveria bassiana tidak membahayakan laba-laba, baik penghuni tajuk maupun tanah di ekosistem padi ratun. Untuk arthropoda golongan herbivora yang datang yaitu walang sangit, ulat grayak, hama putih palsu, penggerek batang dan kepik. Hal ini dapat dilihat pada Gambar 2 dimana arthropoda herbivora yang bersifat hama yaitu walang sangit datang pada minggu ke 5 jumlahnya banyak tetapi mengalami penurunan pada minggu ke 6 setelah dilakukan penyemprotan begitupun pada minggu ke 7 dan minggu ke 8. Populasi walang sangit tetap datang meskipun telah dilakukan penyemprotan akan tetapi Jumlah populasinya mengalami penurunan hal ini sesuai dengan pendapat Syarief (2018) bahwa Beauveria bassiana mampu menekan populasi walang sangit dengan meracuni serangga yaitu kontak dan sistemik dengan memblokir jalannya ion klorida yang membawa asam gamaamino-butirik ke sistem saraf pusat serangga.

Pada perlakuan Beauveria bassiana dosis 1 gram/1,4 liter air memperlihatkan bahwa keanekaragaman arthropoda yang 
ada adalah untuk arthropoda golongan karnivora yaitu laba-laba, capung dan coccinellid. Hal ini dapat dilihat pada Gambar 3 yang menunjukkan bahwa populasi laba-laba dan capung ada ditiap minggunya dan cenderung tidak mengalami penurunan dan untuk arthropoda golongan herbivora yang ditemukan yaitu walang sangit, ulat grayak, hama putih palsu, penggerek batang dan kepik. Hal ini dapat dilihat pada Gambar 4 yang menunjukkan bahwa arthropoda golongan herbivora yang bersifat hama yaitu penggerek batang populasinya tinggi tetapi cenderung mengalami penurunan setelah dilakukan penyemprotan begitu pula dengan populasi walang sangit, ulat grayak, hama putih palsu dan kepik. Menurut Gillespie (1988), salah satu cendawan entomopatogen yang sangat potensial dalam pengendalian beberapa spesies serangga hama adalah Beauveria bassiana (Balsamo) Vuillemin. Cendawan ini dilaporkan sebagai agensi hayati yang sangat efektif mengendalikan sejumlah spesies serangga hama termasuk rayap, kutu putih, dan beberapa jenis kumbang.

Pada perlakuan Metarhizium anisopliae dosis 0,5 gram/1,4 liter liter air, keanekaragaman arthropoda yang ditemukan yaitu arhropoda golongan karnivora dan arthropoda golongan herbivora. Arthropoda golongan karnivora yang ada yaitu laba-laba, capung, kepik predator dan coccinellid. Hal ini dapat dilihat pada Gambar 5 dimana arthropoda karnivora atau musuh alami yang populasinya tinggi yaitu laba-laba jika dibandingkan dengan populasi capung yang juga ada ditiap minggunya, kepik predator dan coccinellid. Menurut Yuliani (2017) Metarhizium anisopliae tidak berdampak buruk terhadap serangga bukan hama sasaran seperti Chironomid dan musuh alami dari $N$. Virescens, yaitu Lycosa pseudoannulata, Cyrtorhinus lividipennis, Sepedon sp., capung jarum, Tipulidae sp., Telenomus sp., capung, dan Tetrastichus sp.. Efikasi Metarhizium anisopliae dan A. paniculata sebagai salah satu strategi pengendalian yang ramah lingkungan dan terbukti tidak membahayakan terhadap serangga bukan hama sasaran.

Arthropoda golongan herbivora yaitu walang sangit, ulat grayak, hama putih palsu, penggerek batang dan belalang. Hal ini dapat dilihat pada Gambar 6 . Arthropoda yang bersifat hama muncul pada minggu ke 4 dan mengalami peningkatan tiap minggunya akan tetapi 
penurunan populasi terjadi pada minggu terakhir. Hal ini menunjukkan bahwa Metarhizium anisoploae mampu menurunkan jumlah populasi hama akan tetapi tidak semua konidia jamur entomopatogen yang diaplikasikan berhasil mencapai sasaran, karena mobilitas serangga yang tinggi dan adanya peristiwa ganti kulit (Prayogo, 2006).

Pada perlakuan Metarhizium anisopliae dosis 1 gram/1,4 liter air diperoleh hasil yaitu keanekaragaman arthropoda yang ada yaitu arthropoda golongan karnivora dan arhropoda golongan herbivora. dimana dapat dilihat pada Gambar 7. Arthropoda karnivora atau musuh alami yang ada yaitu labalaba, capung, kepik predator dan coccinellid dimana jumlah populasi labalaba paling tinggi dibanding jumlah populasi musuh alami lainnya. Arthropoda herbivora atau hama yang ada yaitu walang sangit, ulat grayak, hama putih palsu dan penggerek batang, hal ini dapat dilihat pada Gambar 8 dimana jumlah populasi walang sangit dan penggerek batang mengalami perubahan yang fluktuatif hal ini membuktikan bahwa Metarhizium anisopliae mampu mengendalikan hama tersebut tetapi tidak menutup kemungkinan hama lain untuk datang. Untuk hama ulat grayak dan hama putih palsu mengalami penurunan populasi. Hal ini sesuai dengan pendapat Prayogo (2005) yang menyatakan Metarhizium anisopliae merupakan cendawan entomopatogen yang mempunyai kemampuan menginfeksi beberapa jenis serangga dari ordo Coleoptera, Lepidoptera, Hemiptera, Homoptera, dan Isoptera. Keefektifan cendawan Metarhizium anisopliae dalam mengendalikan Spodeptera litura.

Pada perlakuan Verticillium lecanii dosis $\quad 0,5 \quad$ gram $/ 1,4 \quad$ liter air keanekaragaman arthropoda yang ada pada perlakuan ini yaitu laba-laba. Capung, kepik predator dan coccinellid untuk arthropoda golongan karnivora, walang sangit, ulat grayak, penggerek batang, wereng hijau dan belalang untuk arthropoda golongan herbivora. Untuk arthropoda golongan karnivora, populasinya dapat dilihat pada Gambar 9 yang menunjukkan arthropoda yang besifat musuh alami ini yang paling tinggi jumlah populasinya adalah laba-laba yang ada ditiap minggunya begitupun dengan populasi capung berbeda dengan populasi coccinellid yang muncul pada munggu ke 4 dan kepik predator pada minggu ke 6, jumlah populasi arthropoda golongan 
karnivora terus meningkat karena adanya ketersediaan makanan. Untuk arthropoda golongan herbivora dapat dilihat pada Table 10 dimana semua populasi hama mengalami penurunan. Menurut Vey (2001), Verticillium lecanii mampu menekan populasi artrophoda yang ada dilapangan khususnya yang bersifat hama. Jenis toksin yang dihasilkan oleh Verticillium lecanii adalah cyclosporin A. Antibiotik ini dapat menyebabkan gangguan pada fungsi hemolimfa dan nukleus serangga, sehingga mengakibatkan pembengkakan yang disertai pengerasan pada serangga yang terinfeksi.

Pada perlakuan Verticillium lecanii dosis 1 gram/1,4 liter air keanekaragaman arthropoda yang ada pada perlakuan ini yaitu laba-laba, capung, kepik predator dan coccinellid untuk arthropoda golongan karnivora dan walang sangit, ulat grayak, penggerek batang, wereng hijau, belalang dan kepik untuk arthropoda golongan herbivora. Untuk arthropoda golongan karnivora, jumlah populasinya dapat dilihat pada Gambar 11 dimana populasi laba-laba yang paling tinggi dan ada ditiap minggunya begitu pula dengan populasi capung yang cenderung lebih sedikit tetapi ada ditiap minggunya berbeda dengan coccinellid yang ada pada minggu ke 6 dan mengalami peningkatan pada minggu terakhir dan kepik predator yang hanya ada pada minggu ke 6 . Untuk arthropoda herbivora dapat dilihat pada Gambar 12 dimana populasi walang sangit meningkat pada minggu ke 7 dan mengalami penurunan pada minggu terakhir begitupula dengan penggerek batang dan ulat grayak yang mengalami perubahan yang fluktuatif. Berbeda dengan yang lain, belalang, kepik dan wereng hijau tidak lagi muncul pada minggu terakhir. Cendawan entomopatogen Verticillium lecanii berpotensi menekan perkembangan wereng hijau dengan cara mempengaruhi keperidian serangga betina, namun tidak mempengaruhi kemampuan wereng hijau dalam menularkan virus tungro (Ladja, 2015).

\section{KESIMPULAN DAN SARAN}

\section{Kesimpulan}

Berdasarkan penelitian yang telah dilakukan, maka dapat disimpulkan bahwa:

1) Pemberian Beauveria bassiana, Metarhizium anisopliae dan Verticillium lecanii berpengaruh terhadap populasi tetapi tidak berpengaruh terhadap 
keanekaragaman arthropoda. 2) Masing masing dosis 0,5 gram/1,4 liter air dan 1 gram/1,4 liter air pada masing-masing bioinsektisida efektif menekan populasi arthropoda golongan herbivora.

\section{Saran}

Berdasarkan kesimpulan diatas adapun saran yang dapat diberikan yaitu:

1) Disarankan agar menggunakan Bioinsektisida Beauveria bassiana, Metarhizium anisopliae dan Verticillium lecanii untuk mengendalikan Organisme Pengganggu Tumbuhan. 2) Disarankan agar menggunakan Bioinsektisida Beauveria bassiana, Metarhizium anisopliae dan Verticillium lecanii dengan dosis 50 gram/14 liter air (0,5 gram/1,4 liter air) dengan pertimbangan lebih ramah lingkungan dan lebih hemat biaya.

\section{DAFTAR PUSTAKA}

Aribawa, I. B. (2012). Pengaruh sistem tanam terhadap peningkatan produktivitas padi di lahan sawah dataran tinggi beriklim basah. Paper presented at the Prosiding. Seminar Nasional: Kedaulatan Pangan dan Energi. Fakultas Pertanian Universitas Trunojoyo, Madura.

Gillespie, A. (1988). Use of fungi to control pests of agricultural importance. Fungi in biological control systems, 37-60.
Ginting, A. B. (2012). Kontribusi Usahatani Padi Dan Usaha Sapi Potong Terhadap Pendapatan Keluarga Petani Di Kecamatan Purwodadi Kabupaten Grobogan. Program Pascasarjana Undip.

Herlinda et.al. (2016). Struktur komunitas laba-laba di ekosistem padi ratun: pengaruh aplikasi Beauveria bassiana (Balsamo). Jurnal Entomologi Indonesia, 12(2), 91.

Kartohardjono, A. (2011). Penggunaan musuh alami sebagai komponen pengendalian hama padi berbasis ekologi. Pengembangan Inovasi Pertanian, 4(1), 29-46.

Ladja, F. T., Bulo, L. P. P. T. J., Lanrang Rappang Sidrap, S. S., Santoso, T., \& Nurhayati, E. (2015). Potensi Cendawan Entomopatogen Verticillium lecanii dan Beauveria bassiana dalam Mengendalikan Wereng Hijau dan Menekan Intensitas Penyakit Tungro.

Permadi, M. A. (2010). Patogenisitas beberapa isolat cendawan entomopatogen metarhizium spp terhadap kumbang predator menochilus sexmaculatus f. (coleoptera:coccinelidae). Program studi Agroekoteknologi, BKI Perlindungan Tanaman, Fakultas Pertanian Universitas Andalas, Kampus Limau Manis, Padang 25163.

Prayogo, Y. (2005). Prospek Cendawan Entomopatogen Metarhizium anisopliae untuk Mengendalikan Ulat Grayak Spodoptera litura pada Kedelai. Jurnal Litbang Pertanian, 24(1), 19.

Prayogo, Y. (2006). Upaya mempertahankan keefektifan cendawan entomopatogen untuk mengendalikan hama tanaman pangan. Jurnal Litbang Pertanian, 25(2), 4754. 
Roberts. (1977). Stability of entomopathogenic fungi.

Suwahyono, U. (2009). Biopestisida: PT Niaga Swadaya.

Swastika, D. K., Wargiono, J., \& Pangan, P. T. (2016). Analisis Kebijakan Peningkatan Produksi Padi melalui Efisiensi Pemanfaatan Lahan Sawah di Indonesia.

Syarief, M. F. A. a. K. M. (2018). Status Resistensi Walang Sangit (Leptocorisa acuta F.) Terhadap Insektisida Sintetik dan Kepekaannya terhadap Beauveria bassiana pada Tanaman Padi. Agriprima, Journal of Applied
Agricultural Sciences, Vol. 2, No. 1, Hal. 79-86.

Tanada, Y., \& Kaya, H. (1993). Insect pathology: Academic San Diego, CA.

Vey. (2001). Toxic metabolites of fungal biocontrol agents. In: Butt, T.M., Jackson, C.W., Magan, N. (Eds.), Fungi As Biocontrol Agents: Progress, Problems and Potential. . CABI Publishing(Wallingford, UK), pp. 311-346.

Yuliani, D. (2017). Metarhizium anisopliae dan Andrographis paniculata Terhadap Serangga Bukan Hama Sasaran. Jurnal Ilmu Pertanian Indonesia, 21(1), 20-25. 
Andi Dian Tristiana Kusuma : Efektivitas beberapa Jenis Bioinsektisida terhadap Keanekaragaman dan Populasi Arthropoda pada Ekosistem Padi Sawah

Lampiran 1 Analisis Keanekaragaman Arthropoda

\begin{tabular}{|c|c|c|c|c|c|c|}
\hline \multirow{2}{*}{ sk } & \multirow{2}{*}{ db } & \multirow{2}{*}{$\mathbf{j k}$} & \multirow{2}{*}{ kt } & \multirow{2}{*}{ F hitung } & \multicolumn{2}{|c|}{ F tabel } \\
\hline & & & & & 0.05 & 0.01 \\
\hline Perlakuan & 5 & 8.94444 & 1.78889 & 0.8429319 & 3.32583 & 5.63633 \\
\hline Kelompok & 2 & 10.1111 & 5.05556 & 2.382199 & 4.10282 & 7.55943 \\
\hline Acak & 10 & 21.2222 & 2.12222 & & & \\
\hline Total & 17 & 40.2778 & & & & \\
\hline
\end{tabular}

Lampiran 2 Analisis populasi Arthropoda

\begin{tabular}{|c|c|c|c|c|c|c|}
\hline \multirow{2}{*}{ sk } & \multirow{2}{*}{ db } & \multirow{2}{*}{$\mathbf{j k}$} & \multirow{2}{*}{$\mathbf{k t}$} & \multirow{2}{*}{ F hitung } & \multicolumn{2}{|c|}{ F tabel } \\
\hline & & & & & 0.05 & 0.01 \\
\hline Perlakuan & 5 & 464.444 & 92.8889 & 0.67742 & 3.32583 & 5.63633 \\
\hline Kelompok & 2 & 106.778 & 53.3889 & 0.38935 & 4.10282 & 7.55943 \\
\hline Acak & 10 & 1371.22 & 137.122 & & & \\
\hline Total & 17 & 1942.44 & & & & \\
\hline
\end{tabular}

\section{Lampiran 3 Gambar Keanekaragaman dan Populasi Arthropoda Pada Perlakuan Bioinsektisida}

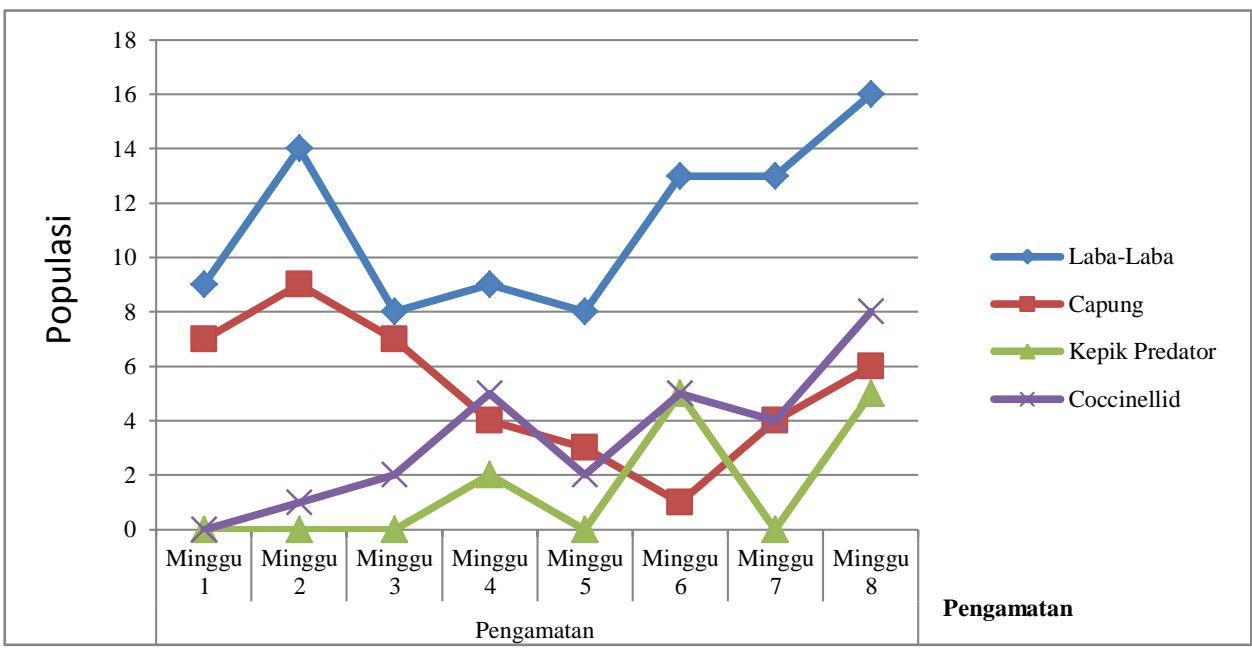

Gambar 2 Keanekaragaman dan Populasi Arthropoda Golongan Karnivora (Musuh Alami) dosis 0,5 gram/1,4 liter air 


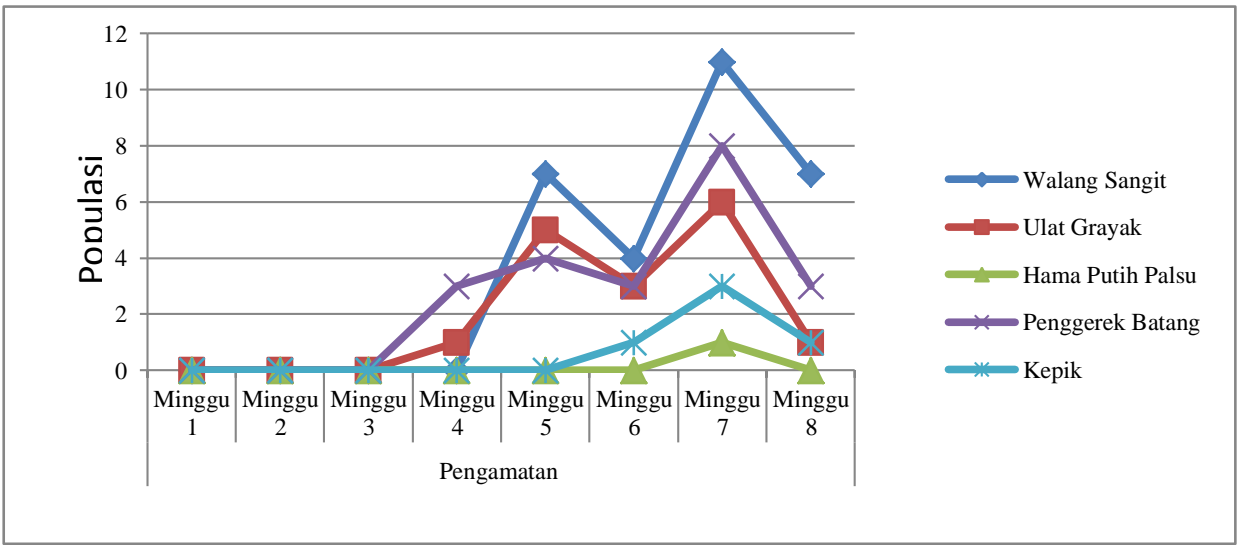

Gambar 3 Keanekaragaman dan Populasi Arthropoda Golongan Herbivora (OPT) dosis 0,5 gram/1,4 liter air

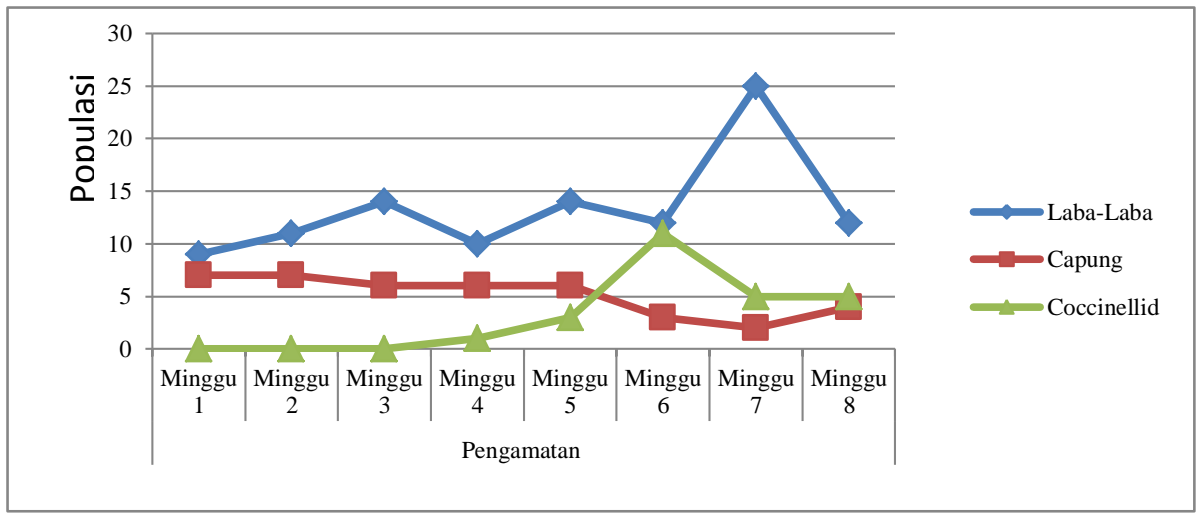

Gambar 4 Keanekaragaman dan Populasi Arthropoda Golongan Karnivora (Musuh Alami) dosis 1 gram $/ 1,4$ liter air

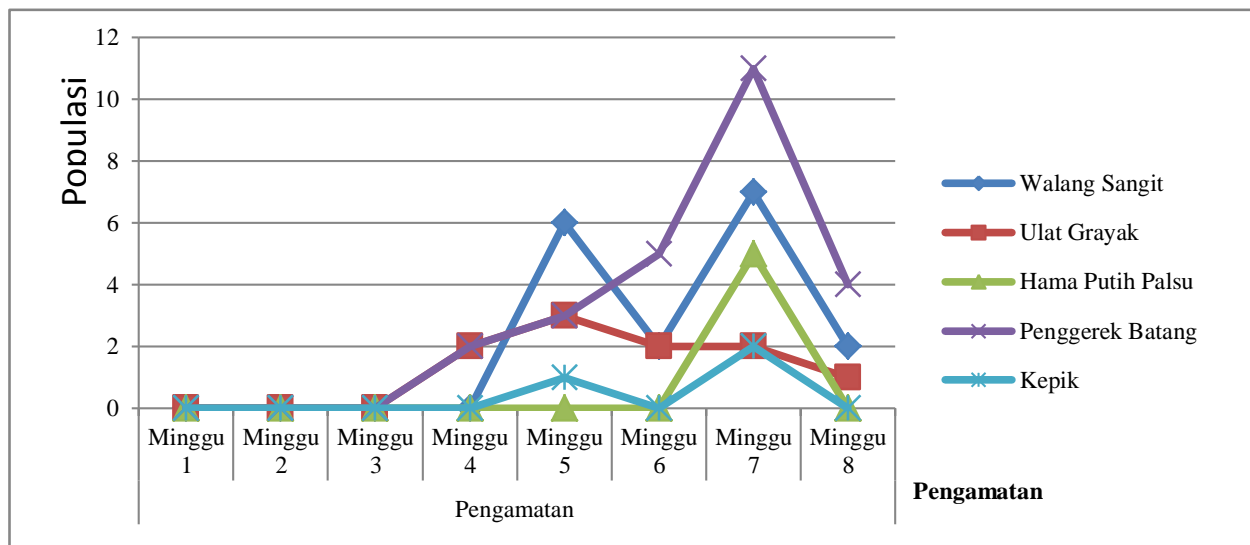

Gambar 5 Keanekaragaman dan Populasi Arthropoda Golongan Herbivora (OPT) dosis 1 gram/1,4 liter air 


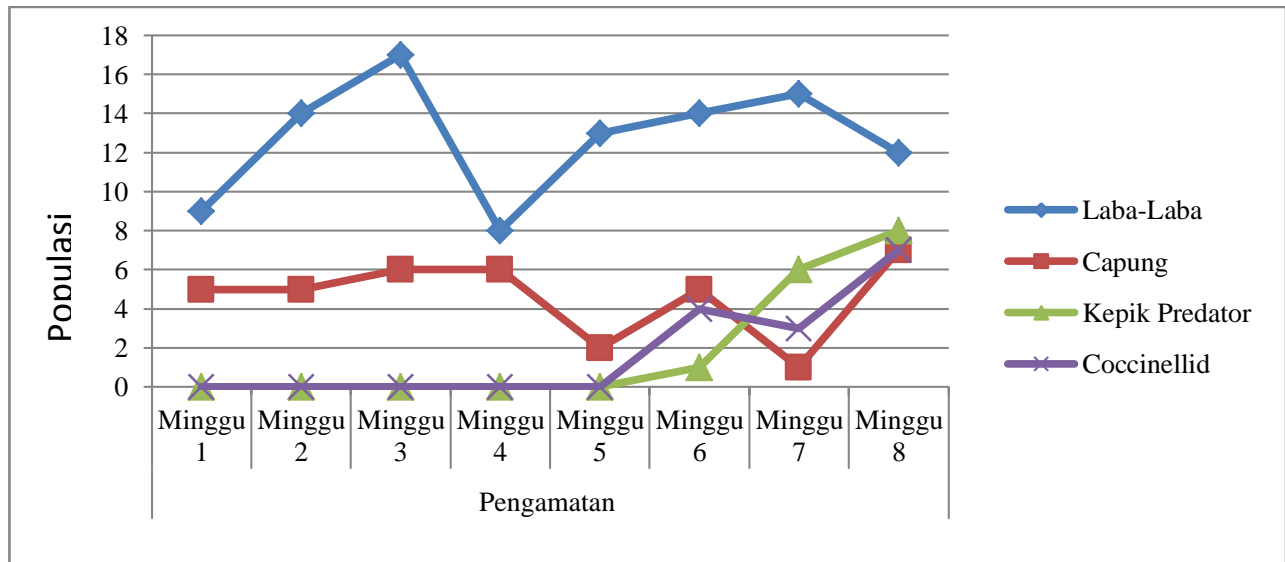

Gambar 6 Keanekaragaman dan Populasi Arthropoda Golongan Karnivora (Musuh Alami) dosis 0,5 gram $/ 1,4$ liter air

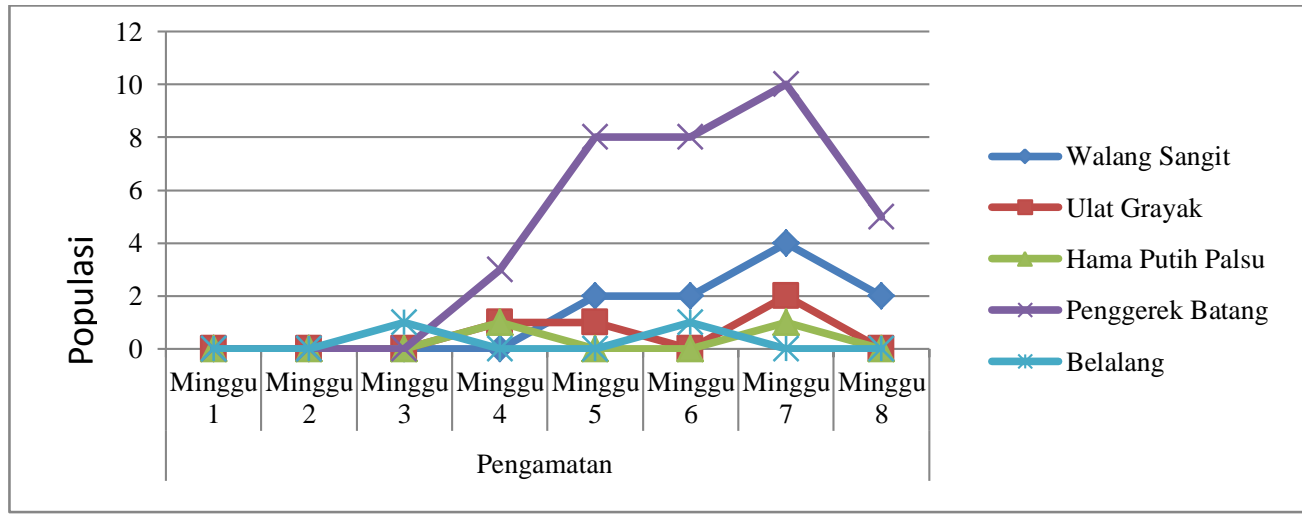

Gambar 7 Keanekaragaman dan Populasi Arthropoda Golongan Herbivora (OPT) dosis 0,5 gram/1,4 liter air

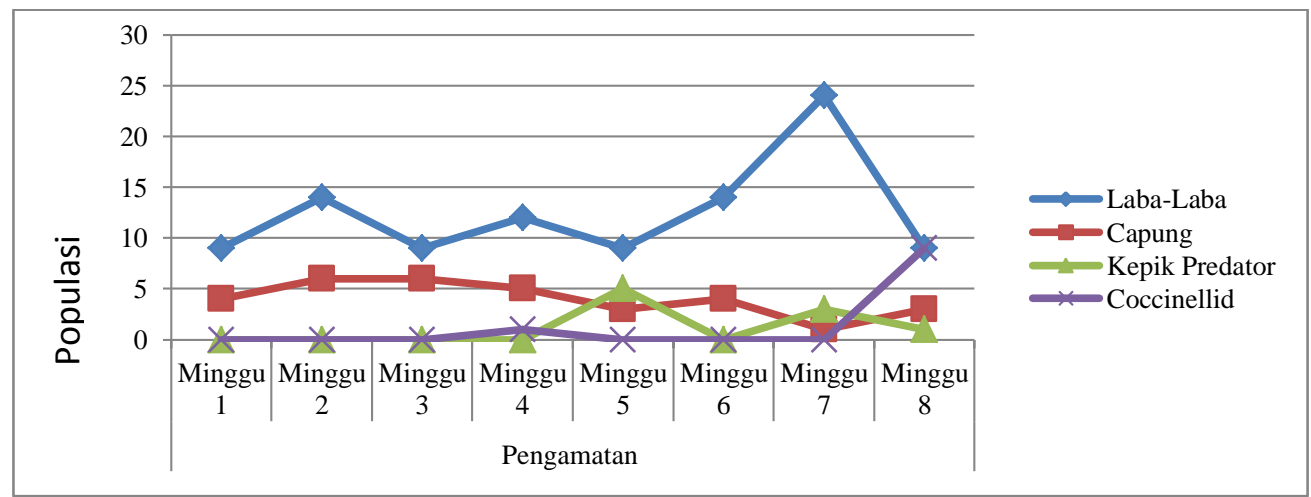

Gambar 8 Keanekaragaman dan Populasi Arthropoda Golongan Karnivora (Musuh Alami) dosis 1 gram $/ 1,4$ liter air 


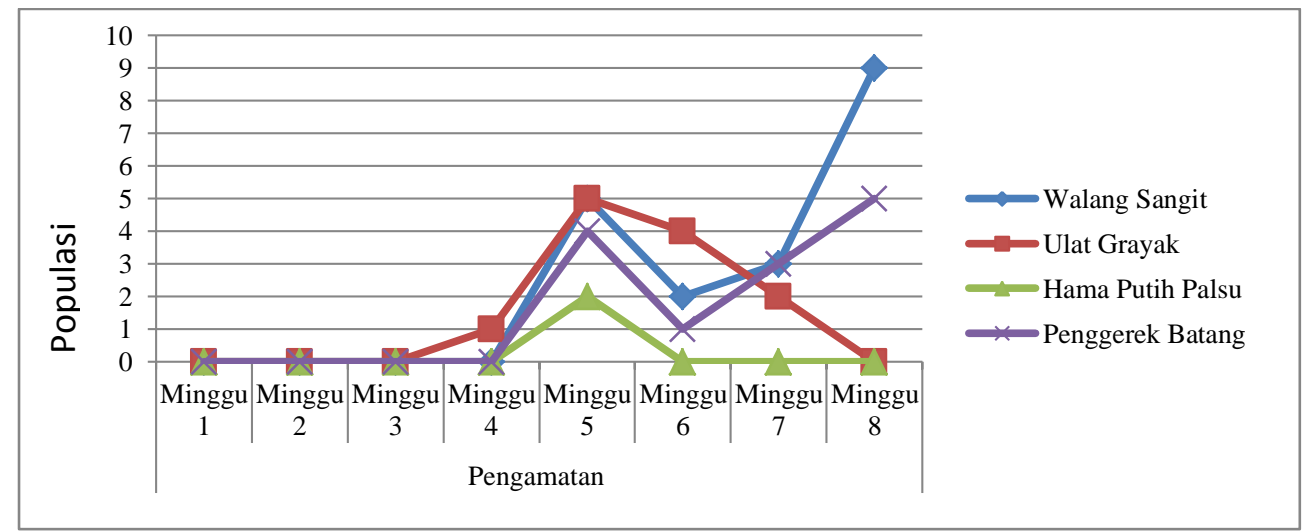

Gambar 9 Keanekaragaman dan Populasi Arthropoda Golongan Herbivora (OPT) dosis 1 gram/1,4 liter air.

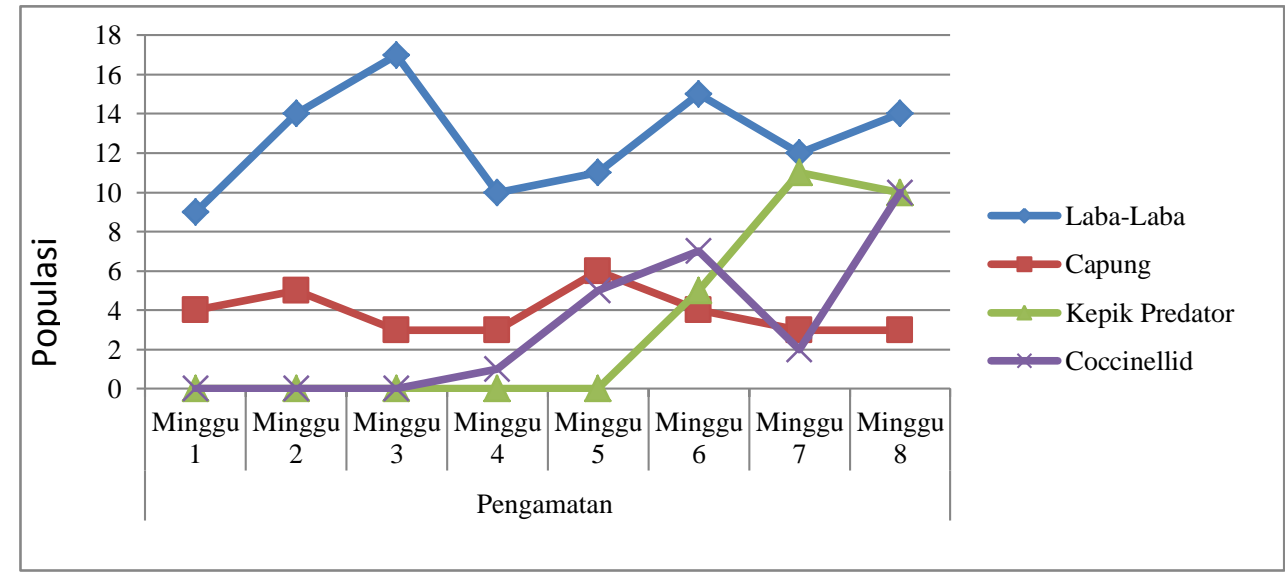

Gambar 10 Keanekaragaman dan Populasi Arthropoda Golongan Karnivora (Musuh Alami) dosis 0,5 gram/1,4 liter air

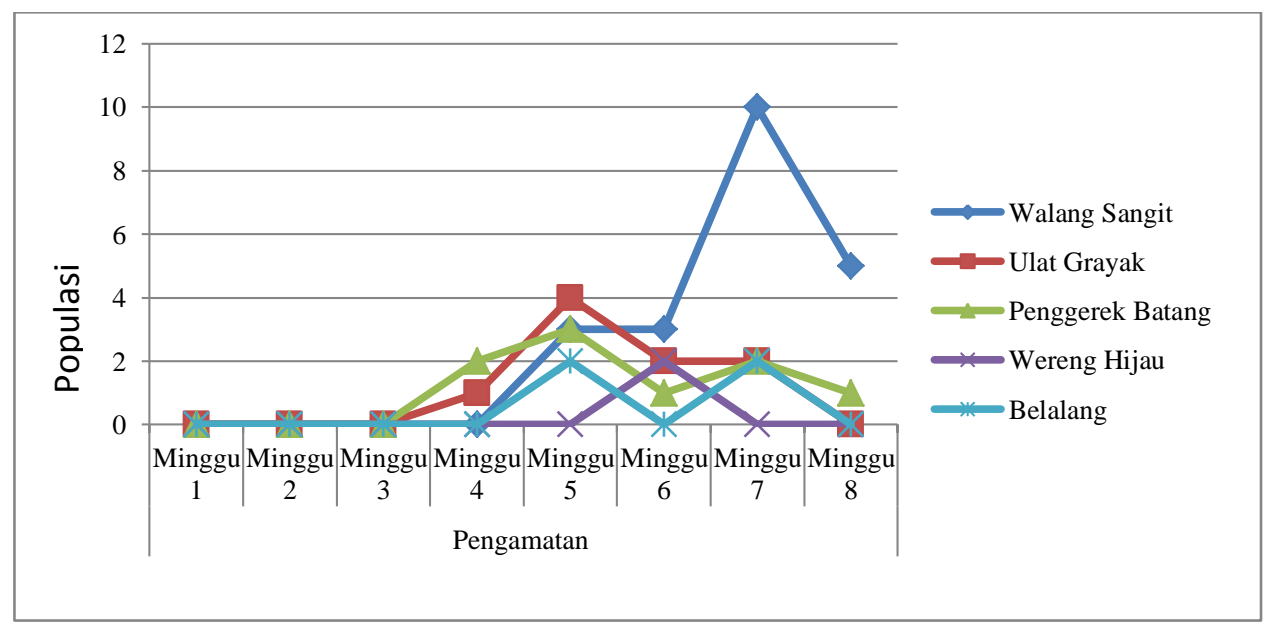

Gambar 11 Keanekaragaman dan Populasi Arthropoda Golongan Herbivora (OPT) dosis 0,5 gram/1,4 liter air 


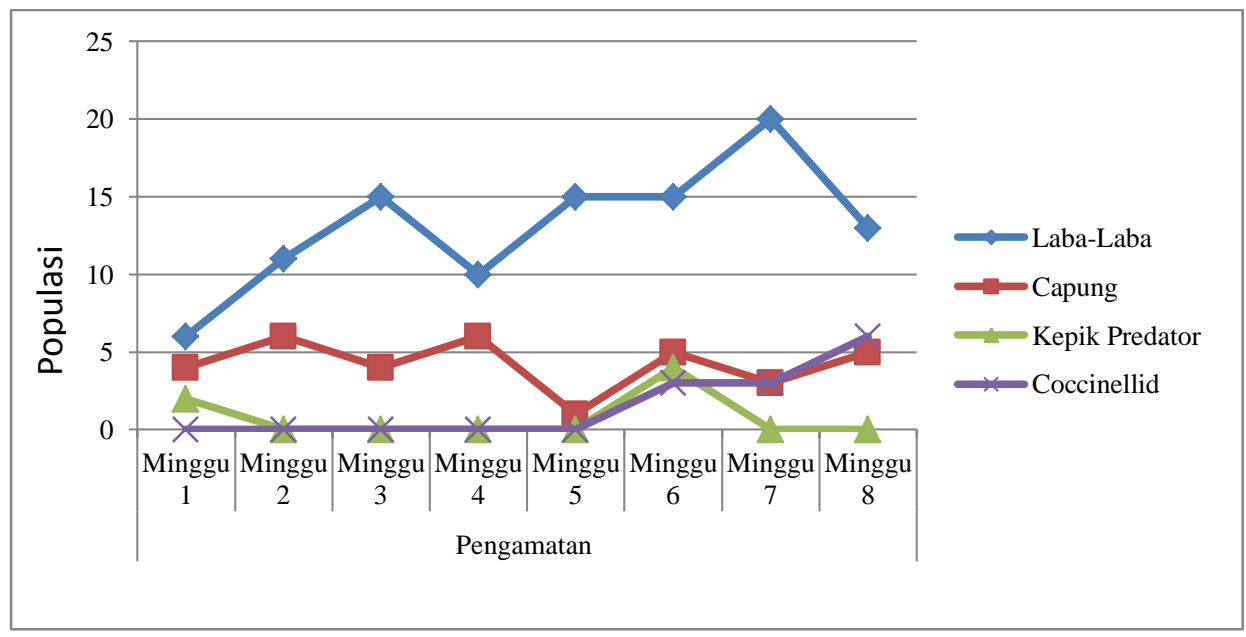

Gambar 12 Keanekaragaman dan Populasi Arthropoda Golongan Karnivora (Musuh Alami) dosis 1 gram/1,4 liter air

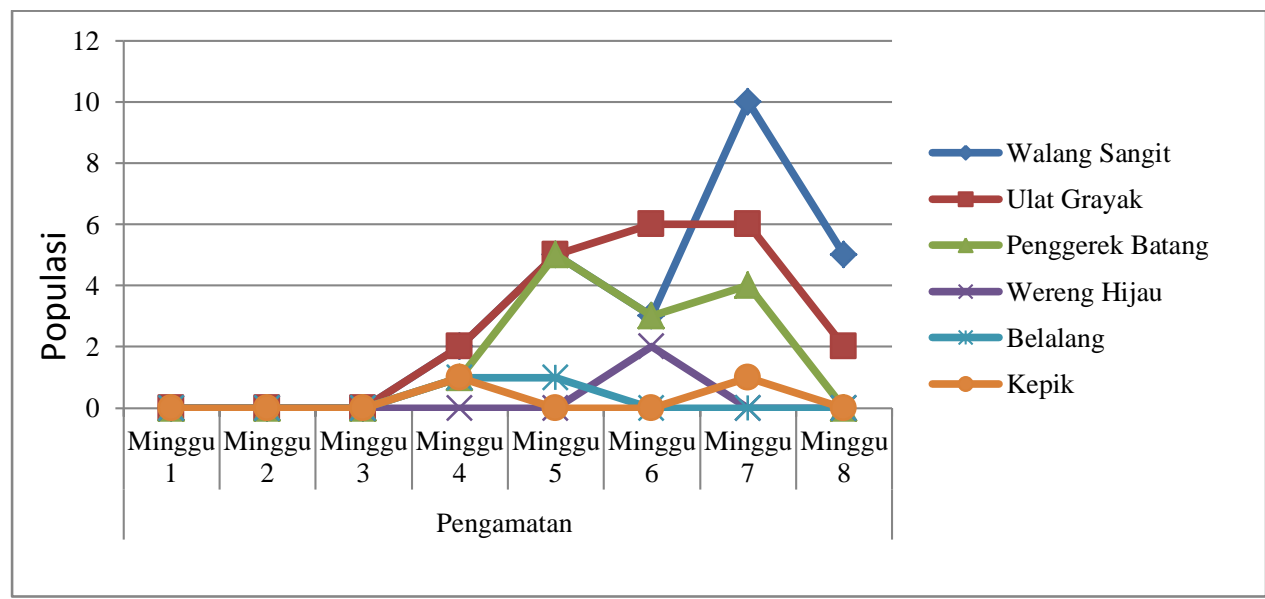

Gambar 13 Keanekaragaman dan Populasi Arthropoda Golongan Herbivora (OPT) dosis 1 gram/1,4 liter air 